\title{
Die betekenis en funksie van die himnes in Openbaring 12- 22
}

\author{
Francois P Viljoen \\ (otchefstroomse Universiteit vir $\mathrm{CHO}$ )
}

\section{ABSTRACT}

\section{The meaning and function of the hymns in Revelation 12-22}

The hymns in Revelation 12-22 function as type of commentary, as they interpret the narrative events of the kernel plot. Being separated spatially and in some instances temporally, the hymns offer interpretations on the events and emphasise the basic themes of God's accomplishment of salvation and judgement through Jesus Christ in the narrative. The final set of hymns in 19:1-8 recall the prior themes recounted through the hymns to form a musical climax. The hymns function as both prolepsis and analepsis in the narrative time, to the creation of the cosmos by God on the one hand, and the final victory of God on the other. As satellelites, the hymns maintain contact with the readers. The hymns function in an assuring sense throughout, constantly reminding of the final victory, one in which the implied reader plays an active role. A better understanding of the use of hymns in Revelation could enrich the use of songs in our liturgy today.

\section{INLEIDING}

Enige navorser wat die betekenis van Openbaring ondersoek, moet deeglik rekening hou met die sleutelrol wat himnes in die narratief speel. Die liedere is funksioneel en kunstig in die struktuur van die teks ingeweef. Hoewel dié liedere funksioneel in enige konteks kan wees, vorm hulle deel van die dramatiese narratief van die boek.

Openbaring veronderstel ' $n$ liturgiese konteks (Charles 1991:463; Floor 1979:135). Die (veronderstelde) leser word genooi om deel te word van die lofprysende gemeenskap waarvan vertel word (Barr 1986:252; Craddock 1986:278; Du Rand 1993b:314). Trouens, talle navorsers het probeer aantoon dat (ten minste sekere dele van) Openbaring op destydse liturgiese patrone gebaseer is (vgl Lauchli 1960:364; Schepherd 1960:47; Thompson 1990:53-73; Vanni 1991:365).

Du Rand (1988:251; 1993a:304-306) toon aan hoe die tema van die ontplooIing van God se verlossing en oordeel deur Jesus Christus as eenheidsbinding in Openbaring dien. Hy gebruik die musikale begrip van basso ostinato ('n grond bas wat uit ' $\mathrm{n}$ kort musikale frase bestaan wat deurlopend voorkom, waardeur ' $n$ musiekstuk tot 'n eenheid saamgebind word) om die eenheid en voortgang in Openbaring te omskryf. Om dieselfde beeldspraak te gebruik sou ' $\mathrm{n}$ mens ook van die Leitmotiv 
(herhaling van tipiese motiewe) kon praat. Met hierdie motief as vertrekpunt, beskou hy Openbaring 12-22 as die derde bedryf van die boek. Daarin word die finale ontvouing van God se verlossing en oordeel in die geskiedenis op grond van die Christus-gebeure vertel.

In hierdie artikel word die betekenis en funksie die liedere wat in hierdie bedryf voorkom ondersoek. Retoriese en narratiewe motiewe word onder andere gebruik om te bepaal hoe die liedere in die teks inpas en in hoeverre die Christusgebeure ook as basso ostinato binne die himnes geld.

Op grond van tekstuele en ko-tekstuele kriteria is die volgende gedeeltes binne Openbaring 12-22 as liedere geidentifiseer (vgl Stauffer 1948:316; Jörns 1971:15-19; Aune 1987:243): 12:10-12; 15:3-4; 16:5-7; en 19:1-8.

Hierbenewens verwys 14:2-3 ook na ' $n$ lied van die honderd vier en veertig duisend op die Sionsberg, hoewel die inhoud van die lied nie weergegee word nie.

\section{RETORIESE FUNKSIE VAN LIEDERE}

Binne die genres van die antieke retoriek, sorteer himnes onder die epideiktiese genre (vgl Kennedy 1984:77). Dit is verwant aan publieke seremonies waarin iemand òf geprys òf gesensureer word. Die doel hiervan is om die gehoor daarvan te oortuig dat iemand se wese en optrede óf eervol óf skandalig is (Kennedy 1980:74). "Eer" en "skande" was twee basiese waardes in die destydse Mediterreense wêreld (Malina 1981:27). ' $n$ Eerwaardige persoon of god is besing op grond van sy wese, maar ook vir sy wonder- en heldedade (paradeigmata) (Harris 1989:276).

Epideiksis word ook dikwels as ' $\mathrm{n}$ performatiewe diskoerstipe geklassifiseer, aangesien dit met seremoniële taal te doen het (Beale 1974:221). So ' $n$ seremonie het onder andere te doen met die uitdrukking van iemand of ' $n$ groep se respek of afkeur van iemand of ' $n$ god.

\section{NARRATIEWE FUNKSIE VAN LIEDERE}

Vanuit ' $n$ narratiewe oogpunt, speel die liedere ' $n$ belangrike funksie in die vertelling. Aune (1987:243) noem die liedere "devices to advance the plot". Dit bied die konteks waarbinne die vertelling ontvou en ' $\mathrm{n}$ vorm waarbinne die verteller die koningskap van God en sy oordele kan realiseer (Thompson 1969:342). Daarbenewens lewer dit kommentaar op die tonele wat beskryf word (Chatman 1978:237-248). In die kommentaar kan die vertelde gebeure vir die leser verduidelik word. Daarbenewens kan die kommentaar die gebeure in die narratief moreel beoordeel. Dit kan ook die oorgang maak vanaf die vertelde wêreld na dié van die leefwêreld van die lesers. Sodoende word die leser by die vertelde wêreld 
betrek en sy interpretasie van die vertelling word gekontroleer (Chambers 1978:331).

Die himnes vorm nie deel van die kern ("kernel”) van die intrige ("plot”) nie, maar vorm wel satelliete ("satellites") waardeur die kern verduidelik word (Barthes 1982:251). "Kernels” beskryf hoofsaaklik die intrige, terwyl "satellites" kommentaar daarop lewer.

Wanneer daar ' $n$ verskuiwing van lokaliteit vanaf die vertelde kern na die satelliete plaasvind, kry die kommentaar wat gelewer word, groter trefkrag (Bal 1985:43-45). Wanneer karakters wat die liedere sing hulle op ' $n$ ander plek as die vertelde intrige bevind, kan hulle as't ware van buite af kommentaar lewer op die gebeure.

' $n$ Nadere ondersoek van die inhoud en struktuur van die himnes in Openbaring 12:10-12, 15:3-4, 16:5-7 en 19:1-8 toon aan hoe funksioneel die liedere is in die finale ontvouing van God se verlossing en oordeel in die geskiedenis op grond van die Christus-gebeure.

\section{OPENBARING 12:10-12}

Openbaring 12 en volgende verse beskryf die stryd tussen die goddelike en bose magte, gepaardgaande met die historiese ontvouing van verlossing en oordeel. Die kritiese oomblik van die verlossing word beskryf met die geboorte van die kind (12:5) terwyl die bose deur die bose trio uitgebeeld word: die draak en die twee diere (12:3-13:18). God oorwin deur die Christus-gebeure.

' $n$ Stem in die hemel het hard uitgeroep om op hierdie gebeure kommentaar te lewer. Johannes gee die woorde van die stem weer (12:10$12)^{1}$ :

\begin{tabular}{|c|c|}
\hline 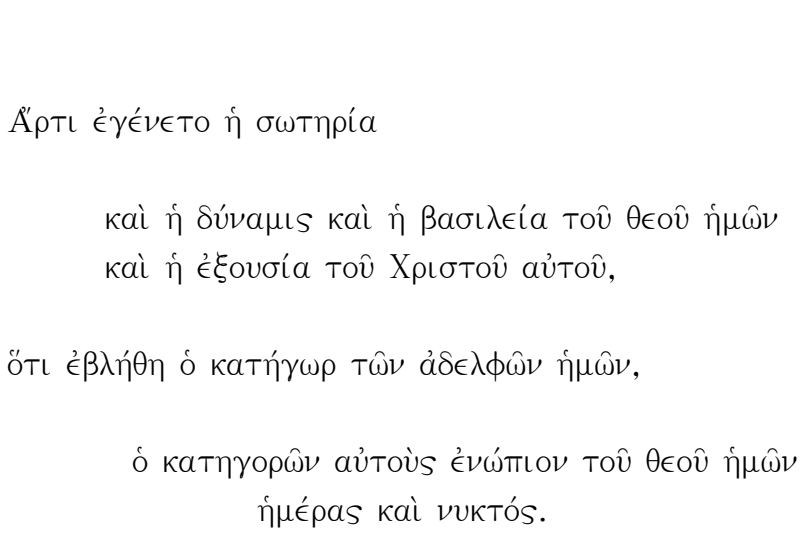 & $\begin{array}{l}\text { Strofe 1: Acclamatio (vers 10): } \\
\text { a. Stelling } \\
\text { "Nou het ons God die redding gebring, } \\
\text { nou is sy mag en koningskap hier, } \\
\text { en die gesag van sy Gesalfde! } \\
\text { b. Oorsaak } \\
\text { Die aanklaer van ons medegelowiges is uit } \\
\text { die hemel uitgegooi, } \\
\text { hy wat hulle dag en nag voor ons God } \\
\text { aangekla het. }\end{array}$ \\
\hline & Strofe 2: Sakrale mite (vers 11): \\
\hline
\end{tabular}

${ }^{1}$ In tabelvorm naas die Griekse teks van die himnes, word die 1983-Afrikaanse vertaling daarvan telkens gegee. 


\begin{tabular}{|c|c|}
\hline 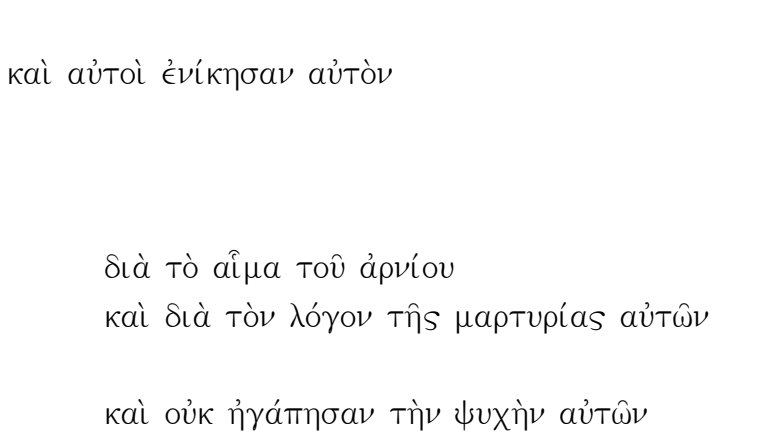 & $\begin{array}{l}\text { a. Stelling } \\
\text { Hulle het self die oorwinning oor hom } \\
\text { behaal } \\
\text { b. Oorsaak } \\
\text { danksy die bloed van die Lam } \\
\text { en die boodskap waarvan hulle getuig het; } \\
\text { en hulle het nie hulle lewens so lief gehad } \\
\text { dat hulle onwillig was om vir Hom te } \\
\text { sterwe nie. }\end{array}$ \\
\hline äxpı Өavátov. & \\
\hline 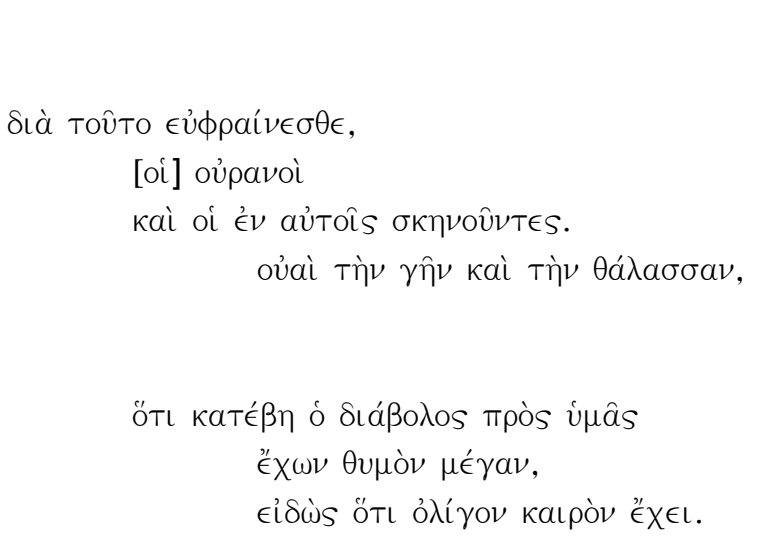 & $\begin{array}{l}\text { Strofe 3: Exhortatio (vers 12): } \\
\text { a. Stelling: } \\
\text { Daarom, hemel en dié wat daarin bly, } \\
\text { verheug julle. } \\
\text { Maar vir julle, land en see, wag daar } \\
\text { ellende } \\
\text { b. Oorsaak: } \\
\text { omdat die duiwel na julle toe gekom het } \\
\text { met groot woede } \\
\text { en met die wete dat hy min tyd het". }\end{array}$ \\
\hline
\end{tabular}

Van wie hierdie stem is, word nie gemeld nie. Van de Kamp (2000:297) bespreek ' $n$ aantal moontlikhede wat deur ' $n$ verskeidenheid van eksegete voorgestel is (engele, 24 ouderlinge, 24 ouderlinge plus 4 lewende wesens, gelowiges in die hemel, martelaars). Al hierdie voorstelle bly spekulatief. Dit is kennelik genoeg om te weet dat daar in die hemel vreugde uitbreek vanweë die oorwinning oor die draak.

Die lied word in die hemel gesing, en lewer dan ruimtelik verwyderde (van buite af) kommentaar op gebeure wat op aarde plaasvind. Op so ' $n$ manier word die lesers gelei hoe om die voorafgaande en daaropvolgende gebeure in die vertelde wêreld te interpreteer.

Hierdie himne herbevestig sommige van die temas (Leitmotiven) wat deel gevorm het van die vorige himnes, byvoorbeeld dat die koningskap, gesag en oorwinning van God gekom het. Gunkel (1966:3264) toon aan dat die tipiese onderbou van hierdie himne gevind kan word in die Siegeslieder (oorwinningsliedere). Daar kom elemente van die Hebreeuse oorwinningsliedere hierin voor (byvoorbeeld Eks 15:18; 1 Sam 12:12; Ps 145:11ev, Jes 24:23; 33:22) wat intertekstueel hier geeggo word.

Die himne is waarskynlik uit drie strofes opgebou, as acclamatio, “sakrale mite” en exhortatio (Barkhuizen 1989:14; Du Rand 1993b:322). 
Die strofes is aldrie as parallelle opgebou waardeur die stellings beklemtoon word en die oorsake genoem word.

Strofe 1 kondig met ' $n$ stelling die deurbraak van God se verlossing, krag en koninkryk asook Christus se gesag aan. Hierdie aankondiging oorheers die boodskap van die himne. Die groot keerpunt word onder woorde gebring: "nou is die oorwinning behaal". Die dinamiek waarmee God sy reddingswerk doen, het nou duidelik geword. In die hemel is God se koninkryk gevestig en die gesag van sy Gesalfde het aan die lig gekom. Na hierdie stelling in die strofe, volg die oorsaak van die stelling. Migael het die aanklaer van die gelowiges uit die hemel uitgegooi. Daar het ' $n$ einde gekom aan die stem van die aanklaer, wat dissonant deur die engelesang geklink het. Hierdie strofe eggo Psalm 2: die hemel lag oor die geweld van die draak (Van de Kamp 2000:298).

In die tweede strofe word die geheim van die oorwinning onthul. Vanuit die retories-kritiese benadering word die tweede strofe ' $n$ "sakrale mite" genoem (Du Rand 1993b:322). Hierdie benaming is ontleen van Menander wat agt tipes himnes onderskei het wat aan gode gesing is (vgl Harris 1989:275). ' $n$ Mitiese himne bevat verhalende elemente waarin die helde-dade van die god vertel word. In hierdie strofe word die reddingsdaad van die kind van die vrou voor sy hemelvaart besing. Deur sy bloed het Hy redding vir die gelowiges gebring.

Die tweede strofe begin met ' $n$ stelling van hierdie oorwinning. Die term "oorwin" vorm ' $\mathrm{n}$ sleutelwoord in Openbaring (Van de Kamp 2001:175). Die bloed van die Lam (die Kind van die vrou) het die redding gebring, omdat God op grond daarvan vergewing kon skenk. So deel die mede-gelowiges in die oorwinning van die Lam. Die stelling word met ' $\mathrm{n}$ oorsaak gevolg waarin twee sake genoem word waaruit die oorwinning van die gelowiges oor die satan blyk. In die eerste plek word die getuienis van die gelowiges genoem. "Het belijdend spreken van de gelovigen is iets waar satan niet tegen kan" (Van de Kamp 2000:299). Daarbenewens word hulle getrouheid aan God selfs ten koste van hulle lewens genoem.

Daarop volg die exhortatio in strofe 3 . Die strofe begin met die stelling dat aangesien die aanklaer nie meer die hemel kan ingaan nie, daar nou in die hemel rede tot vreugde is. In die hemel is daar geen dreigende gevaar meer nie. Die oproep dat die hemel hulle moet verheug is te verstane in die lig daarvan dat die alles oorkoepelende hemel getuie is van die dade van God. ' $n$ Mens sou verwag dat die aarde en see ook nou tot vreugdebetoning opgewek sou word, maar die lied neem ' $n$ vreemde wending. ' $n$ Uitroep van ellende volg. Die oorsaak van die ellende word vervolgens genoem. Die duiwel wil sy nederlaag op aarde gaan wreek. Die draak is los, en benader die aarde met groot woede. Die waarskuwing aan die aarde en see is egter ingebed in die hemelse 
feeslied. Die vreugde oor die opruiming van die hemel hou groot belofte ook vir die see en die aarde in. Binnekort sal dit daar ook opgeruim word (20:1-3, 7-10). Implisiet spreek hierdie vreugdelied die lesers aan: die teenstander kan oorwin word deur moedige gedrag, selfs met die dood voor oë. In die volgende episode word hierdie oproep van die himne in beeldryke taal onderstreep.

Die himne in 12:10-12 lewer kommentaar deur regstreeks na die gebeure van 12:1-9 te verwys en dit te interpreteer (Du Rand 1993b:323; Harris 1989:157). Die kommentaar volg op die deurslaggewende gebeurtenis toe die duiwel uit die hemel gegooi is (12:9). Satan is oorwin. Die himne vertel die presiese rede waarom die Satan uit die hemel gegooi is en wat hy voorheen daar gedoen het. Die narratief van Openbaring het sy klimaks bereik. God is die oorwinnaar. In dié opsig is die himne analepties van aard.

Die himne is egter ook prolepties binne die konteks van die narratief. Soos met die himne in 11:17-18, kyk hierdie himne ook vorentoe na gebeure wat nog moet volg. Vers $12 \mathrm{~b}$ is in werklikheid ' $\mathrm{n}$ waarskuwing aan diegene op die aarde teen die toekomstige optrede van die satan.

Hierdie himne het ' $n$ sterk ideologiese impak aangesien dit die oorwinning van die satan koppel aan die martelaarskap van die gelowiges. ' $n$ Direkte verband word getrek tussen die martelaarskap van die Lam en van die gelowiges. Daarbenewens verwys dit na ' $n$ kosmiese hernuwing gebaseer op goddelike triomf oor die chaos van die teenwoordige wêreld. Die chaos sal egter vervang word met ' $\mathrm{n}$ orde van vrede en voorspoed (Aune 1987:228). In die opsig verwys die himne na die gebeure wat in Openbaring 13 volg.

\section{OPENBARING 15:3-4}

Die himne in 15:3-4 is ' $\mathrm{n}$ respons op die groot en indrukwekkende dinge wat Johannes in die hemel sien. Voorts bied dit ' $n$ interpretasie en kommentaar op hierdie voorafgaande gebeure. Dit dien ook as inleiding tot die visioene (tonele) van die sewe plae wat in 15:1-16:21 volg. Voor die ontvouing van die sewe finale plae, word die gelowiges verseker van hulle geloof in God deur sy dade in herinnering te roep, waarop hulle met vrees en lofprysing antwoord (15:3-4):

\begin{tabular}{|c|c|}
\hline 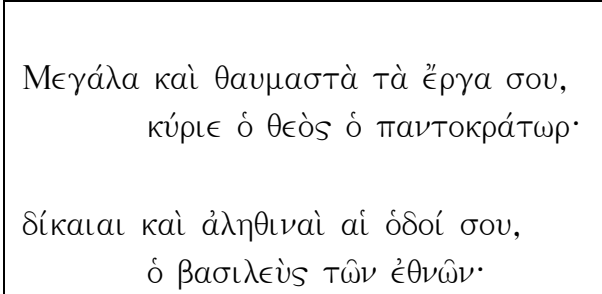 & $\begin{array}{l}\text { Strofe 1: Doksologie: Acclamatio (vers 3) } \\
\text { "Groot en wonderbaarlik is u dade, } \\
\text { Here God, Almagtige. } \\
\text { Reg en betroubaar is u optrede, } \\
\text { Koning van die nasies. }\end{array}$ \\
\hline
\end{tabular}




\begin{tabular}{|c|c|}
\hline 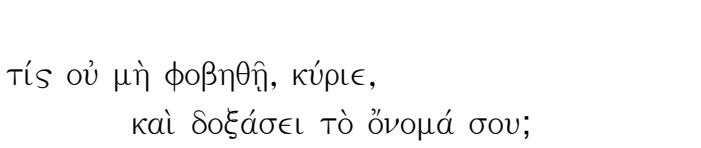 & $\begin{array}{l}\text { Strofe 2: Exhoratio: Retoriese vrae (vers 4a) } \\
\text { Wie sal U nie vrees nie, Here, } \\
\text { en u Naam nie verheerlik nie? }\end{array}$ \\
\hline 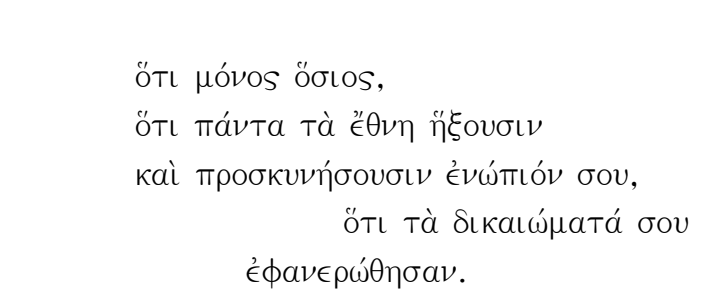 & $\begin{array}{l}\text { Strofe 3: Doksologie: Redes (vers } 4 \mathrm{~b} \text { ) } \\
\text { U alleen is heilig! } \\
\text { Al die nasies sal kom en U aanbid, } \\
\text { want hulle sal sien dat u handelswyse regverdig } \\
\text { is”. }\end{array}$ \\
\hline
\end{tabular}

Johannes tipeer die lied wat hy hoor as die lied van Moses en van die Lam. Hierdie lied verwys (15:3) intertekstueel na die lied van Moses in Eksodus 15:1-8 (en Deuteronomium 32:1-43) wat as voorbeeldlied vir hierdie lied oor die Lam in Openbaring dien ${ }^{2}$. In die Moses-lied (Eksodus 15) het Israel hulle dank aan God betuig vir die verlossing wat Hy bewerk het deur die plae en oordele waarmee Hy die Farao getref het. Die himne in Openbaring 15 bewoord dat God se dade weer eens bewondering afdwing. God se almag blyk uit sy vernietigende gerig. Daarin is Hy regverdig en betroubaar. Die slae waarmee God die vyand tugtig, hou bevryding in vir sy volk.

Op grond van hierdie intertekstuele verwantskap met Eksodus 15, besing ook die Openbaring 15 lied bevryding as 'n nuwe eksodus van politieke, kulturele en religieuse verdrukking. Die betekenis van die gebeure in Openbaring het betrekking op die Eksodus-gebeure wat hier sintagmaties in Openbaring aan die orde kom (vgl. Floor, 1969:243; 1979:127; Stanley 1958:183; Van de Kamp 2000:355). Floor (1969:211) noem dit "de voltooiing van de nieuwe exodus". Die intertekstuele toepassing van die Eksodus-motief gee aan die dier die konnotasie van ' $n$ politieke onderdrukker, soos die geval was met die Farao. Die Romeinse onderdrukkers sou beskou kon word as Farao redivivus (Harris 1989:172).

Hierdie himne kan in drie strofes verdeel word en as doksologie geklassifiseer word. Strofes 1 en 3 is parallel in die sin dat albei doksologieë bevat. Strofe 1 bevat doksologiese akklamasie (acclamatio), terwyl strofe 3 doksologiese redes verwoord. Deur middel van retoriese vrae in strofe 2 word die leser met 'n oproep (exhortatio) betrek by die doksologiese aanbieding van die himne (Du Rand 1993b:327). Op so ' $n$ manier word die gelowiges versterk, terwyl hulle herinner word aan die groot dade van God (Du Rand 1995:203).

\footnotetext{
${ }^{2}$ Vergelyk Viljoen (2001:432-434) oor die gebruik van Ou Testamentiese liedere in die Nuwe Testament.
} 
Die doksologie van strofe 1 toon aan dat God se (voorafgaande en volgende) dade bewondering afdwing. Die lof op God se dade is ' $\mathrm{n}$ tema wat in talle psalms voorkom (vg. Ps 92:5; 11:2; 139:14). God se almag blyk ook uit sy regverdige oordele (soos ook besing is in die lied van Moses) en die name waarmee Hy aangespreek word ("Here God, Almagtige" en "Koning van die nasies"). God word soortgelyk in die liedere van 4:11 en 11:7 aangespreek.

Die tweede strofe is saamgestel uit ' $n$ dubbele retoriese vraag. Hierdie vrae eggo die vrae in Jeremia 10:6-7. Die hele wêreld sal skrik as hulle God se optrede sien. Die vrae vorm die middelstrofe van die lied. Die vrae is gefundeer in die lofprysing en aanspreekvorme van God in die eerste en derde strofes.

Parallel aan die eerste strofe, volg daar weer 'n doksologie in strofe 3. Hierdie strofe bied die redes vir die voorafgaande lofprysing en retoriese vrae. God is onvergelyklik groot. Hy alleen moet gevrees en aanbid word, nie ook die draak en sy twee monster-helpers nie.

Die lied in Openbaring 15:3-4 kombineer die oorlog- en eksodusmotief in Openbaring. As God as koning heers, kan Hy die onreg van die bose nie ongestraf laat nie. Sy oordeel moet kom (Boring, 1986:259). Die volk van God wat die koninkryk van God met dié lied verkondig, beleef die nuwe eksodus waar die koninkryk van God op aarde gevestig word. Die oorwinning in die hemel is behaal. God bewerk redding en oordeel op aarde. Die gelowiges hoef nie te vrees of beangs te raak nie. God se oorwinning is deurslaggewend. Die tugtiging van God se vyande het die bevryding van sy volk as keersy.

So lewer hierdie himne kommentaar op die gebeure van Openbaring 13. Aangesien die himne die eksodus-motiewe buite die narratiewe wêreld van Openbaring betrek, lewer die himne morele kommentaar deur die gebeure te boordeel in die lig van die Eksodusgebeure.

Uit hierdie verwysing, word ook die betekenis van die "nuwe lied" in Openbaring duidelik. Die lied in Openbaring is nuut, want dit is ' $n$ aanpassing en nuwe toepassing van die lied van Moses (Jörns 1971:127). Die lied is geinkorporeer in die Jesus tradisie. Die verlossing van Openbaring oortref die verlossing van die Farao.

Op grond van ideologiese en fraseologiese motiewe, verwys hierdie himne ook terug na die himne tot eer van God in Openbaring 4. Ook daar is na Hom verwys as die "Almagtige" (4:8) en "heilige" (4:8), terwyl die noodsaaklikheid ook beklemtoon is dat sy Naam verheerlik moet word (4:11). Wat in Openbaring 4 dus die vertrekpunt van die 
ouderlinge en die lewende wesens was, word nou ook die lied van die martelaars.

Soos die geval was met die vorige himnes, is ook die himne in Openbaring 15 analepties sowel as prolepties in die narratief. Die nasies wat in 15:4 genoem word, verwys klaarblyklik terug na 144000 verseëldes wat in 7:4 en weer in 14:1 genoem word. Prolepties verwys dit aan die ander kant na 21:22-27.

\section{OPENBARING 16:5-7}

Die bakvisioene (Openbaring 15 en 16) word geinterpreteer deur die himne in 16:5-7. Nadat die toneel van die eerste drie oordeelsbakke wat uitgegiet is, volg die lied van die engel wat oor die water toesig hou (16:5-6):

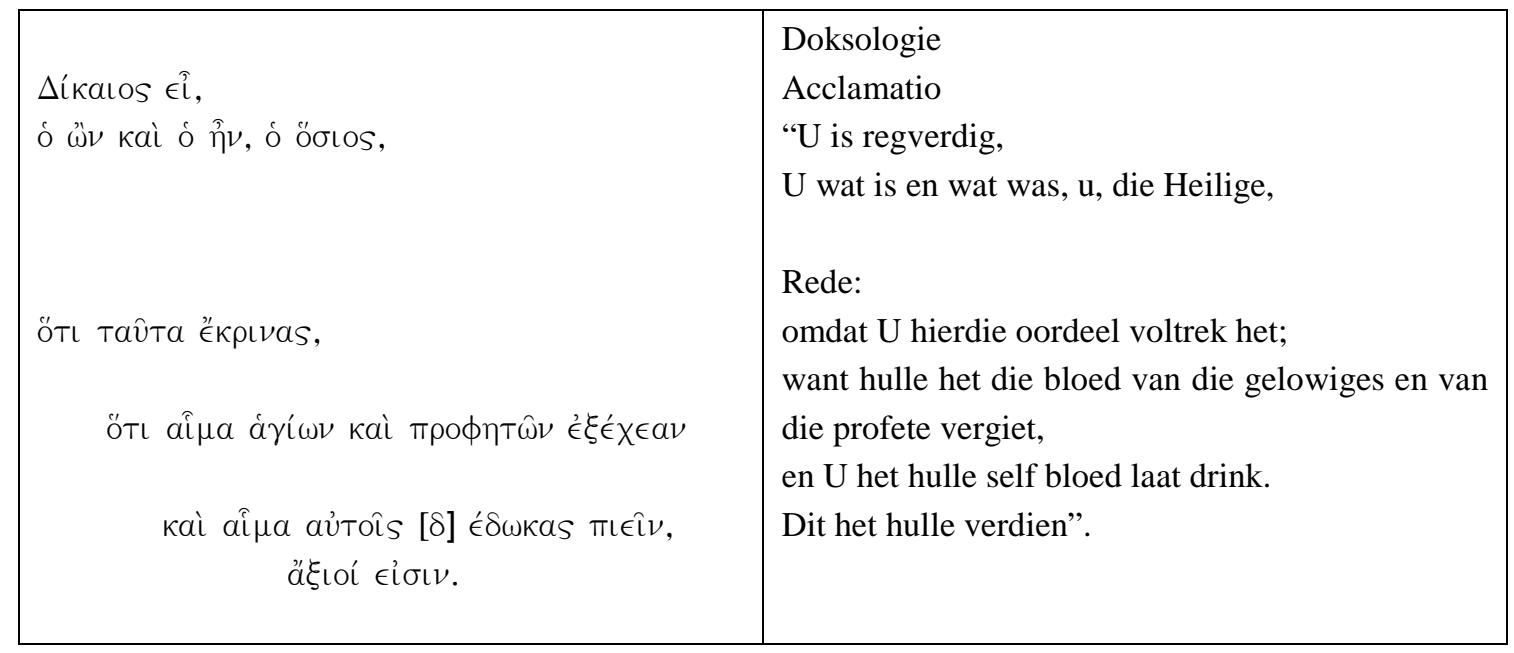

Die engel wat by die altaar toesig hou, het antifonies daarmee ingestem (16:7):

\begin{tabular}{|c|c|}
\hline 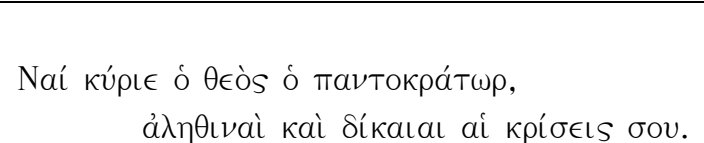 & $\begin{array}{l}\text { Doksologie (acclamatio in respons) } \\
\text { “Ja, Here God, Almagtige, } \\
\text { betroubaar en reg is u oordele”. }\end{array}$ \\
\hline
\end{tabular}

Hierdie twee in een himne besing die regverdige oordele van God en staan bekend as "oordeelsdoksologie" (Harris 1989:176). Heelwat navorsing oor hierdie himnes is vanuit die form-kritiese benadering gedoen (vgl Betz 1969:139; Stapels 1972:281). Daarvolgens word dit as 'n eskatologiese wraakformule beskou. Hierdie formules sou gebruik word om mense tot bekering op te roep, met verwysing na 9:20-21 en 16:21 (Collins 1977:369). Binne die konteks van Openbaring 16 het 
hierdie formule egter duidelik met die oordeel oor die vervolgers van die gelowiges te doen.

Die twee-in-een himne is ' $n$ doksologie wat parallel opgebou is. Dit begin met ' $n$ acclamatio, gevolg deur ' $n$ rede daarvoor deur die engel van die water. Die engel van die altaar respondeer daarop met ook ' $\mathrm{n}$ acclamatio, parallel met die eerste een.

Die eerste himne word deur ' $\mathrm{n}$ nuwe karakter in die narratief gesing, die engel wat in beheer staan van watervoorsiening. Dié lied interpreteer die eerste drie plae. Dit beklemtoon die riviere wat bloed word (16:4), deur regstreeks daarna te verwys (Collins 1977:373, Jörns, 1971:137-138). Hierdie water wat in bloed verander eggo en herinner aan die eerste plaag toe Israel uit Egipte verlos is (Eksodus 7). Die engel sing 'n himne waarin hy straffende oordeel van God deur hierdie drinkwaterrampe as verdiend en regverdig besing. Soos die himne in 15:3-4, is hierdie himne ook binne sy spesifieke konteks geinkorporeer, terwyl dit elemente uit die vorige himnes herhaal, soos " $U$ is regverdig", "U wat is en wat was", "U die heilige". Soos in die himne van 11:15-18 ontbreek die verwysing na God se koms in die toekoms ("Hy wat kom") wat in die himne van 4:8 wel voorkom. Die gebeure wat in Openbaring 6 beskryf is, beskryf sy koms eksplisiet. Met die oordele blyk dit trouens dat God reeds gekom het.

Na die akklamasie volg die rede van die doksologie. Dit verwys na die vergrype wat roep om bestraffing. Die toediening van die plae word as uitvoering van God se reg geprys. Die vergelding is duidelik: wie bloed vergiet, kry bloed om te drink. Waar bloed in Bybelse tyd gewoonlik die konnotasie van lewe gedra het, word dit hier die setel van dood (Van de Kamp 2000:358).

Ideologies gesproke, is die rede wat vir die akklamasie gegee word vol ironie. In 5:9 word besing dat die Lam waardig is om die boek te neem, omdat Hy gemartel is. Dieselfde term word in 16:6 gebruik om aan te toon dat die onderdrukkers van die gelowiges waardig is om deur die goddelike plae getref te word. Hierdie term is waarskynlik doelbewus gebruik om die ironie te beklemtoon dat die Lam waardig is om die eer en heerlikheid te ontvang, en die gelowiges saam met Hom. Al wat die onderdrukkkers waardig is, is om die oordeel te ontvang.

In antifoniese respons op die vorige lofprysing betoon die engel van die altaar sy instemming met die regverdigheid van God se vonnisse. Die altaar is die plek waar die siele om wraak geroep het (6:9 en 9:13-14) (Van de Kamp 2000:359). Nou het dit gebeur. Hierdie lied herhaal die beskrywing "Almagtige” (16:7), wat ook in 4:8 en 11:17 gebruik is. In 
die huidige konteks word die Leitmotiv van God se almag nie net bevestig nie, maar ook gedemonstreer.

Hierdie twee-in-een himne interpreteer die gebeure wat vertel word. Die leser kan die verloop van die gebeure begryp.

\section{OPENBARING 19:1-8}

Na die bak-visioene word die triomf van die almagtige God oor die ontugtige Babilon (17:1-20:3, 7-10) vertel. Die regverdiges word opgeroep om hulle te verheug oor die regverdige oordeel van God (18:20).

Daarop word verskillende lofsange weergegee as himniese finale wat by hierdie klimaks van die narratief hoort. Die lof van drie groepe word weergegee, die van die engele ${ }^{3}(19: 1-3)$, die vier en twintig ouderlinge en vier lewende wesens (19:4) en van die gelowiges (19:6-8). Hierdie drievoudige lofprysing vorm ' $n$ kontras met die drievoudige roubetoon in 18:9-19.

' $n$ Groot menigte in die hemel sing ' $n$ lied waarin God besing word vir sy oorwinning, heerlikheid en mag (19:1-2):

\begin{tabular}{|c|c|}
\hline 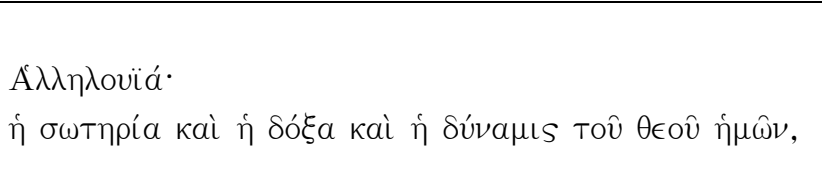 & $\begin{array}{l}\text { Acclamatio } \\
\text { "Prys die Here! } \\
\text { Die oorwinning, die heerlikheid en die } \\
\text { mag behoort aan ons God! }\end{array}$ \\
\hline 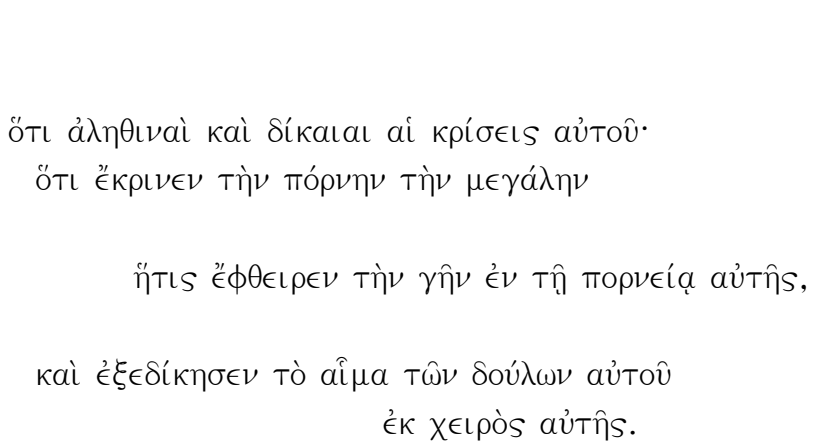 & $\begin{array}{l}\text { Rede: } \\
\text { Regverdig en reg is sy oordele, } \\
\text { want Hy het die oordeel voltrek oor die } \\
\text { sedelose vrou } \\
\text { wat die aarde deur haar onsedelikheid } \\
\text { verwoes het. } \\
\text { Hy het die dood van sy dienaars op haar } \\
\text { gewreek". }\end{array}$ \\
\hline
\end{tabular}

Die eerste doksologie is opgebou uit 'n akklamasie en 'n meervoudige rede daarvoor. Die teenwoordige bose wêreld wat deur die sedelose vrou beheer word, word getermineer deur goddelike intervensie (Aune 1987:227). Die bestraffing van die sedelose vrou word deur die himne verduidelik as die antwoord van God op die versoek van die martelaars

${ }^{3}$ Sommige navorsers is van mening dat die menigte na die martelare verwys, soos in 7:9) (vgl Macleod 1999:74). 
om reg (6:10). God se trou word besing in die nakoming van sy belofte deur die vrou wat die aarde bederf het te oordeel en die vergote bloed te wreek.

Vir ' $n$ tweede keer, as antifoniese tussenspel, besing dieselfde koor die Here oor die vernietiging van Babilon (19:3):

\begin{tabular}{|c|c|}
\hline 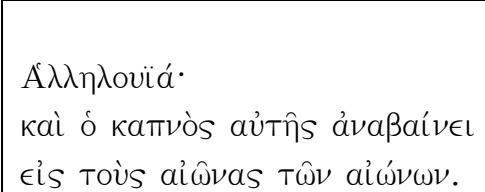 & $\begin{array}{l}\text { Acclamatio } \\
\text { "Prys die Here! } \\
\text { Haar rook styg } \\
\text { tot in alle ewigheid op". }\end{array}$ \\
\hline
\end{tabular}

In aansluiting by 18:8 word die definitiewe van Babilon se ondergang uitgedruk in die verklaring dat haar rook tot in alle ewigheid sal opstyg. Hierdie oordeel eggo die profesie teen Edom (Jes. 34:10) en die oordeel oor Sodom en Gomorra as ' $n$ altyd rokende puinhoop.

Hierdie tweevoudige himne (19:2-3) eggo die inhoud van 4:11; $5: 12,13 ; 7: 10$ en 12:10-11. Dit dig aan God oorwinning toe, soos in die himnes van 7:10 en 12:10, en eer en krag, soos die himnes van 4:11 en 5:13. In dié opsig herhaal dit die temas van die vorige himnes. Dit voorsien kommentaar op die gebeure in Openbaring 17 en 18 deur te bevestig dat die oordeel oor die sedelose vrou regverdig is. Dit herhaal ook die ideologie van 16:5 waar die oordeel van die eerste drie bakke aangekondig is.

Die vier en twintig ouderlinge en die vier lewende wesens sluit by die lofprysing aan. Hulle kniel en aanbid God met lofprysing (19:4):

\begin{tabular}{|c|c|}
\hline 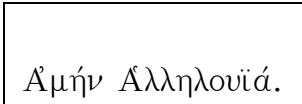 & $\begin{array}{l}\text { Acclamatio } \\
\text { "Amen! Prys die Here!”. }\end{array}$ \\
\hline
\end{tabular}

Met "amen” betuig hulle hulle regstreekse instemming met die optrede van God en die voorafgaande lofprysing. Daarby voeg hulle met "halleluja” hulle eie lofprysing.

Hierna volg die stem wat al God se dienaars oproep om in hierdie lofprysing te deel (19:5):

\begin{tabular}{|l|l|}
\hline Aỉveît $T \hat{\varphi} \theta \in \hat{\varphi} \dot{\eta} \mu \hat{\omega} \nu$ & $\begin{array}{l}\text { Exhortatio } \\
\text { Loof ons God, } \\
\text { al sy dienaars, }\end{array}$ \\
\hline
\end{tabular}




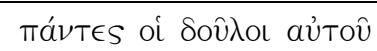

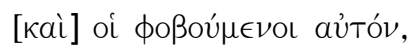

oi $\mu$ кроі кaì oi $\mu \in \gamma a ́ \lambda o l$.
Dié wat Hom vrees,

klein en groot!”

Waarskynlik kom hierdie oproep van die vier lewende wesens of van die vier en twintig ouderlinge wat ook in vers 4 aan die woord was. Hierdie oproep sluit aan by die begin van Psalm 134 en 135. Hierdie oproep bied ' $\mathrm{n}$ konkretisering van die "halleluja-roep" van die vorige verse.

Daarop val die menigte van God se dienaars neer en dit klink soos die gedruis van baie watermassa en soos die gedreun van swaar donderweer (19:6-8):

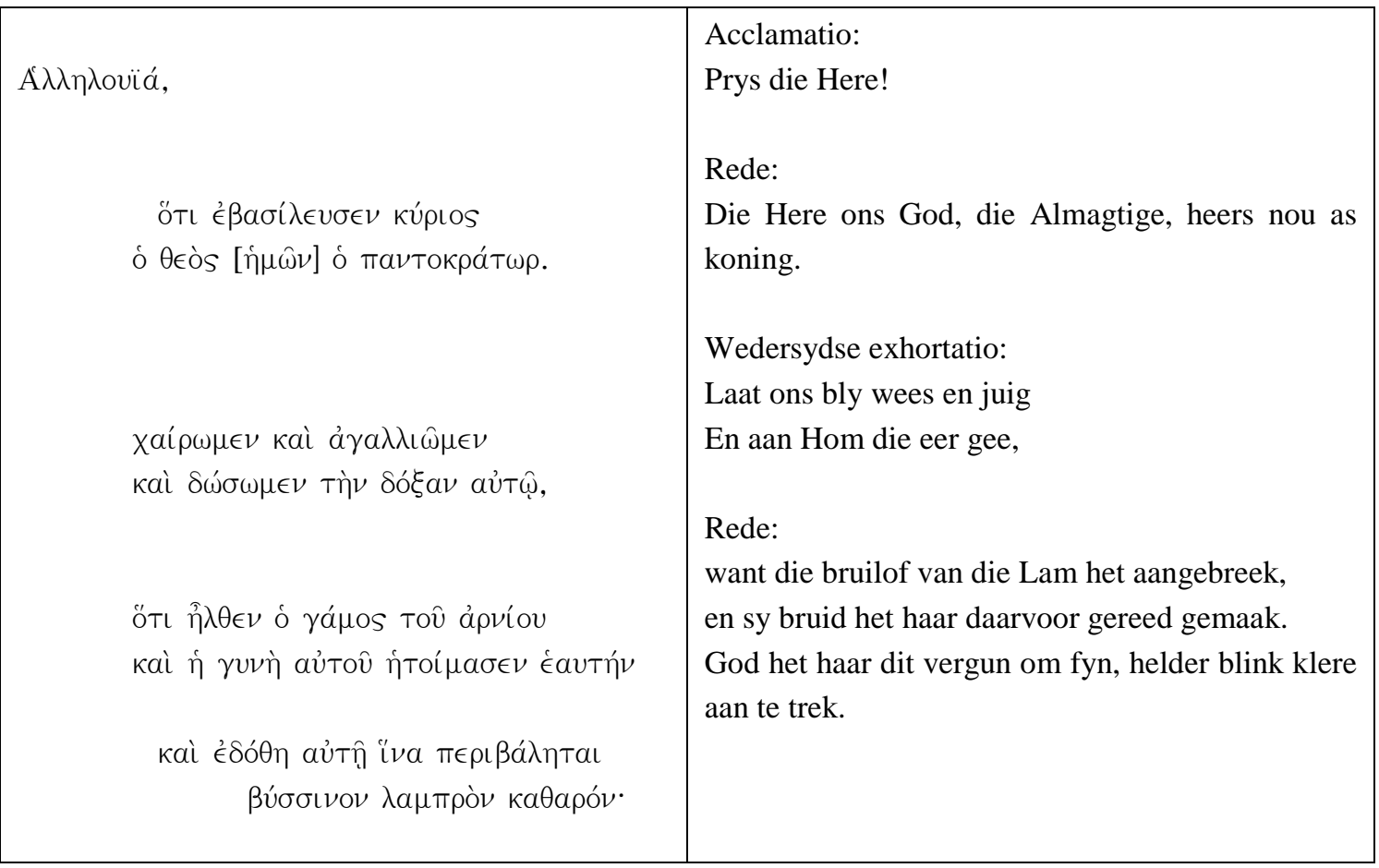

Vir die derde keer hoor Johannes die halleluja-roep as acclamatio, in antwoord op die oproep van vers 5. Daarna word die rede van die lofprysing genoem. Die val van Babilon word aangedui as die manifestasie van God se koninklike heerskappy. God se koningskap word gevestig as die magte van die bose vernietig is. Volgens hierdie liedere word die oordeel gepas en regverdig gesien (Floor 1979:137; Macleod 1999:76). Hierdie himne (19:6) herhaal elemente van 11:15-18. Die Here God heers nou as koning. God word geprys omdat Hy die slegte vrou, die bose religieuse mag, wat haar so sterk in die wêreld gevestig het, geoordeel het. Die benaming "Almagtige” prys God teen die agtergrond van die Romeinse trots as diegene wat alles onder beheer het (Van de Kamp 2000:424; 2001:172). Domitianus, wat op daardie stadium keiser 
was, het homself as dominus et deus noster (die here en ons god) laat verklaar (Macleod 1999:77). Volgens die sangers is die Almagtige egter die Here ons God.

$\mathrm{Na}$ die acclamatio volg ' $\mathrm{n}$ wedersydse exhortatio waarin die sangers mekaar oproep tot blydskap, vreugdebetoon en lofprysing van God. As keersy op die lofroep vanweë die val van Babilon volg hierdie lofprysing, omdat die tyd van die bruilof aangebreek het. Terwyl die eerste himne (19:2-3) die val van Babilon, wat in die vorige hoofstukke beskryf word, analepties interpreteer, kyk die tweede himne (19:6-8) vorentoe (prolepties) na die bruilofsfees van die Lam (21:9-27). Hierdie himne verwys vooruit na die klimaks van die vertelling, naamlik die bruilofsfees van die Lam met die bruid (21:2,9).

Die bruid staan in teenstelling met die owerspelige vrou. Die beeld van die bruid word ook in die Ou Testament gebruik om die kerk te beskryf (bv Hos 2:16, Jes 54:5-7; Eseg 16:17). Die vreugde van die bruilofsfees is in die Ou Testament ' $n$ beeld vir die vreugde van die messiaanse eindtyd (Jes 61:10; 62:5). Die kleed van die bruid word vir haar gegun. Dit slaan op God se aktiwiteit in die gee van die bruilofskleed. Tegelyk klee sy haarself, wat dui op eie aktiwiteit. Die bruilofskleed eer nie die draer daarvan nie, maar die gewer (Van de Kamp 2000:424). Die kleding simboliseer dat die bruid waardig geag word om deel te kry aan die bruilofsmaal van die Lam. Dit staan ironies in teenstelling met die waarde-oordeel oor die owerspelige vrou wat werd is om geoordeel te word.

Hierdie is die laaste himnes in die narratief. Soos verwag kan word, bevat dit elemente van die vorige himnes, terwyl dit ook na die slot van die vertelling verwys. Hulle lewer paslike kommentaar op die voorafgaande vertelling van God se oordeel en is geintegreer in die onmiddelike konteks.

Drie van die vier himnes begin met "Halleluja" (prys die Here). Hoewel hierdie uitroep volgens die Ou Testament gereeld in die tempel in Jerusalem geklink het, is hierdie die enigste plek in die Nuwe Testament waar hierdie liturgiese uitdrukking voorkom. Dit was 'n uitdrukking wat veral in die hellenistiese Joodse erediens gebruik is, en kom in talle psalms voor (bv 104:35; 105:45; 106:48). Die term is dikwels in verband met die Paasgebeure gebruik. Psalm 113-118 staan byvoorbeeld bekend as die Paas-hallel. Die term sou in verband staan met die verlossing van die volk van God, terwyl die onderdrukkers vernietig word (Macleod 1999:74). As voortvloeisel hiervan is die term ook in sekere kontekste gebruik om die koms van messiaanse koninkryk te vier (Jörns 1971:145). Die herhaling van "Halleluja" gee aan die lofsange 'n besondere beklemtoning en maak daarvan die klimaks van die lofprysings. Die 
hallelujas begin in die hemel, maar die gelowiges op aarde sluit daarby aan.

Hierdie halleluja is besonder funksioneel in narratief van Openbaring. Die lesers word ook by die gebeure betrek (Craddock 1986:178; Boring 1986:269). Klimakties word hulle daaraan herinner dat alles voorspoedig sal afloop, hoewel hulle vir 'n tydlank sal moet ly. Die hallelujas verseker hulle dat God wel in beheer is. Hy sal die orde herstel. Gelowiges wat nou verneder word, sal die hoogste in eer ontvang. Dit gee hoop en perspektief. Die liedere het ' $n$ terapeutiese uitwerking op die lesers. Die kerk van toe en nou word uitgenooi om aan te sluit by die Hallelujas, want "Die Here ons God, die Almagtige, heers nou as koning”.

\section{GEVOLGTREKKINGS}

Die himnes lewer kommentaar op die gebeure wat in Openbaring 12-22 beskryf is. Die himnes is narratiewe satelliete wat kommentaar lewer op die vertelde gebeure in die intrige. Die singers van die himnes in 15:3-4 en 19:1-8 is ruimtelik verwyderd van die gebeure en kan daarom as't ware van buite af kommentaar lewer op die gebeure. Die himnes in 12:10-12 en 15:3-4 is temporeel verwyderd van die gebeure waarop hulle kommentaar lewer, waardeur daar klem geplaas word op die interpretasie. Die himnes in 19:1-8 het ' $n$ spesiale plek in die temporele spektrum in die sin dat die slot vorm van die oordeel op die aarde, maar vooruit kyk na toekomstige gebeure.

Die himnes het ' $\mathrm{n}$ belangrike funksie aangesien dit die basiese temas (Leitmotiven) aanbied, wat die intrige genereer. Die temas van God se oorwinning oor die bose magte deur Jesus Christus en die koms van sy koninkryk, die regverdigheid van sy oordele en die redes vir die satan se nederlaag word in die himnes verwoord.

Die laaste himnes (19:1-8) herhaal al die kerntemas wat in die vorige himnes aan die orde gekom het en vorm so die musikale klimaks.

Die himnes funksioneer as prolepsis sowel as analepsis binne die narratief. Analepses is geleë in die Satan wat uit die hemel gegooi is (Op 12). Die belangrikste prolepsis is geleë in die voortdurende herinnering aan die koms van die koninkryk van God en die oorwinning oor die bose magte.

As satelliete funksioneer die himnes om kontak met die leser te hou. Die liedere vertel voortdurend vir die leser dat daar sinvolle narratiewe aksies plaasgevind het en nog sal plaasvind. 
Die himnes funksioneer deurgaans terapeuties. Die himnes bied bemoediging, herinner voortdurend aan die eindoorwinning waarbinne die veronderstelde leser ' $n$ aktiewe rol speel.

Hoewel die intrige van Openbaring 12 tot 22 moontlik sonder die weergawe van die himnes vertel sou kon word, kon die totale kommunikatiewe en estetiese effek nie daarsonder bereik word nie.

' $n$ Liturg wat geleer het om Johannes se besondere effektiewe aanwending van liedere in die hoor en sien ervaring van sy veronderstelde lesers (en hoorders) te gebruik, vind daarin 'n goudmyn vol informasie oor hoe liedere vandag in die erediens aangewend kan word.

\section{Literatuurverwysings}

Aune, D 1987. The New Testament in its literary environment. Philadelphia: Westminster Press.

Bal, M 1985. Narratology: Introduction to the theory of narrative. Toronto: University of Toronto Press.

Barkhuizen, J H 1989. Inleiding. In: Barkhuizen, J H (red) Hymni Christiani. Hervormde Teologiese Studies Supplementum I, 1-16.

Barr, D L 1986. The Apocalypse of John as oral enactment. Interpretation, 40(3), 243-256.

Barthes, R 1982. Introduction to the structural analysis of narrative, In: Sontag, S (ed) A Barthes reader. New York : Hill \& Wang, 251-295.

Beale, W H 1974. Rhetorical performative discourse: a new theory of Epideictic. Perspectives in Religious Studies, 11, 221-246.

Betz, H D 1969. On the problem of the religio-historical understanding of Apocalypticism. JTC, 6, 134-156.

Boring, M E 1986. The theology of Revelation: "The Lord our God the Almighty reigns”. Interpretation, 40, 257-269.

Chambers, R 1978. Commentary in literary texts. Critical Inquiry, 5, 323-337.

Charles, J L 1991. An apocalyptic tribute to the Lamb (Rev 5:1-14). Journal of the Evangelical Theological Society, 34(4), 461-473.

Chatman, S 1978. Story and discourse. Ithaca: Cornell University Press.

Craddock, F B 1986. Preaching the book of Revelation. Interpretation, 40(3), 270282.

Collins, A Y 1977. The History-of-Religions Approach to Apocalypticism and the “Angel of the waters" (Rev 16:4-7). Catholic Biblical Quarterly 39, 367-381.

Du Rand, J A 1988. Die Openbaring aan Johannes. Inleiding tot die Openbaring aan Johannes. In: Du Toit, A B (red). Handleiding by die Nuwe Testament. Pretoria: NG Kerk Boekhandel, 219-252.

-, 1993a. A 'basso ostinato' in the structuring of the Apocalypse of John? Neotestamentica 27(2), 299-311.

-, 1993b. "Now the salvation of our God has come". A narrative perspective on the hymns in Revelation 12-15. Neotestamentica 27(2), 313-330. 
-, 1995. The song of the Lamb because of the victory of the Lamb. Neotestamentica 29(2), 203-210.

Floor, L 1969. De nieuwe Exodus. Representasie en inkorporatie in het Nieuwe Testament. Potchefstroom: Potchefstrooms Universiteit vir CHO (Th.D Proefskrif).

-, 1979. Het gericht van God volgens het Nieuwe Testament. Amsterdam: Buijten \& Schipperheijn.

Gunkel, H 1966. The Psalms: A form-critical introduction. Philadelphia: Fortress.

Harris, M A 1989. The literary function of hymns in the Apocalypse of John. Ann Arbor: University Microfilm International (Ph.D Thesis).

Jörns, K-P 1971. Das hymnische Evangelium: Untersuchungen zu Aufbau. Funktion und Herkunft der hymnische Stücke in der Johannesoffenbarung. Gütersloh: Verlagshaus Gerd Mohn.

Kennedy, G A 1980. Classical rhetoric and its Christian and secular tradition form ancient and modern times. Chapel Hill: University of North Carolina Press.

-, 1984. New Testament interpretation through rhetoric criticism. Chapel Hill: University of North Carolina Press.

Lauchli, S 1960. Eine Gottesdiensdienststruktur in der Johannesoffenbaring. Theologische Literaturzeitung 16, 359-378.

Macleod, D J 1999. Heaven's Halleluja Chorus: An introduction to the seven last things (Rev 19:1-10). Bibliotheca Sacra 156, 72-84.

Malina B, 1981. New Testament world: Insights from cultural anthropology. Atlanta: John Knox Press.

Shepherd, M H 1960. The Paschal liturgy and the Apocalypse. Richmond: John Knox.

Stanley, D M 1958. Carmenque Christo quasi deo dicere . Catholic Biblical Quarterly 20, 173-181.

Stapels, P 1972. Rev. xiv and its vindication formula. Novum Testamentum 14, $280-$ 293.

Stauffer, E 1948. Die Theologie des Neuen Testaments. Hüttersloh: Bertelsmann.

Thompson, L 1969. Cult and eschatology in the Apocalypse of John. Journal of Religion 49, 330-350.

-, 1990. The book of Revelation. Apocalypse amd empire. Oxford: Oxford University Press.

Van de Kamp, H R 2000. Openbaring, profetie vanaf Patmos. Kampen: Kok.

-, 2001. Horen en bewaren. Enkele opmerkingen over de etische diemensie van de Openbaring aan Johannes. In: Van Houwelingen, P H R, Van de Kamp, H R \& Meijer, J A reds. Exeget[h]isch, feestbundel voor prof. dr J van Bruggen. Kok: Kampen, 165-183.

Vanni, U 1991. Liturgical dialogue as a literary form in the Book of Revelation. New Testament Studies 37, 348-372.

Viljoen, F P 2001. Song and music in the Pauline epistles. Paul's utilisation of Jewish, Roman and Greek musical traditions to encourage the early Christian communities to praise God. In die Skriflig 35(3), 423-442. 